\title{
Aesthetics of 1950 s and 1960s interiors presented in Polish comedy films from that period
}

\begin{abstract}
Wojciechowska-Kucięba Joanna, Aesthetics of 1950 s and 1960s interiors presented in Polish comedy films from that period. "Images" vol. XXII, no. 31. Poznań 2017. Adam Mickiewicz University Press. Pp. 81-90. ISSN 1731-450X. DOI 10.14746/i.2017.31.08.

This article is an attempt at outlining key aesthetic standards of interior design of the 1950s and 1960s on the basis of examples exhibited in the Polish and foreign romantic comedies of that time. Some distinguishing features of 1950s Polish aesthetics were the characteristic abstract language, organic form, asymmetry, diagonal lines, arrangements based on " $\mathrm{A}$ " and " $\mathrm{X}$ " letter outlines and lively colours. Furniture design used new materials mostly plywood and plastics such as polyvinyl chloride and epoxy resins.

The 1960s, called "small stabilization" by design historians, were slightly different. Shops offered a variety of new products designed by Polish creators - such as furniture, home appliances, tools and machines. New Polish industrial design of 1960s is represented by the RAMONA and EWA radios and the BAMBINO record player, whereas sectional furniture - especially SYSTEM MK designed by Bogusława and Czesław Kowalski, better known as "the Kowalskis' furniture" - became the icon of the decade.

Polish and foreign romantic comedies from 1950s and 1960s are an excellent iconographic source of information on how interior design changed in the second half of the 20th century, and specifically on how living space was organized and adapted for private and public purposes. In Poland, attempts were made to use all the "design innovations" coming from the west, however, the immutably closed Polish borders prevented them from spreading freely. We had to use local designers. In the 2nd half of the twentieth century, a period which Prof Irena Huml called "the invasion of modernity" started. The doctrine of socialist realism was rejected and the focus was on modernity. Innovation became the most desirable feature of a work of art, and modernity the most important concept.
\end{abstract}

Keywords: aesthetic, Adolf Dymsza, Andrzej Łapicki, Breakfast at Tiffany's, Sylwester Chęciński, Tadeusz Chmielewski, comedy film, design, Eams, Jan Batory, Jan Fethke, Garsoniera, Władysław Hańcza, Jan Rybkowski, Wanda Telakowska, Irene, Go Home, A Cure for Love, There is No Free Lunch, Kalina Jędrusik, Krystyna Sienkiewicz, Sabrina, Leon Jeannot, The Marriage of Convenience, Man with an Apartment, Matter to Be Settled, Daniel Olbrychski, Our Folks, Thonet, Andrzej Wajda, Lidia Wysocka, Magdalena Zawadzka

The artistic visions of directors, since the beginnings of the history of motion pictures, have influenced our aesthetic sensitivity and have stunned us with the visual form of the subject. Films tell that are fixed in the consciousness, much more than a strictly literary record not supported by a moving picture. This process can becarried out in different ways: more artistic or more based on a documentary representation of reality. Scenography has become not only a background for acting, but also an important commentary on the visual and aesthetic reality.

\section{Images} vol. XXII/no. 31 Special Issue Poznań 2017 ISSN 1731-45OX 
In Poland in the first half of the post-war decade, the dominant doctrine was that of realism in form and socialism in content. Industrial design was of marginal interest to the authorities it was however, just like all other areas of life of the Poles subject to centralized control. The [1950]s were not an easy period for Polish aesthetics, and consequently, for industrial design. In [1950] the Biuro Nadzoru Estetyki Produkcji (Production Aesthetics Supervision Bureau) was disbanded and in its place the authorities established the Instytut Wzornictwa Przemysłowego (Industrial Design Institute), which has operated ever since.[1] The majority of authors formerly connected with BNEP began working with the new institution. Wanda Telakowska, [2] appointed the Deputy Chairman and responsible for the artistic side of the Institute's operations, had to adapt the previous, quite liberal guidelines to the new political situation.[3] One year previously, power in Poland had been finally taken by the communists, who imposed "socialist realism" [4] as the only artistic doctrine, and began to stress the need to introduce folk inspirations in the theory of industrial design. Therefore the IWP devoted its efforts to implementing the experiences and standards of small-scale folk manufacturing in the conditions of large-scale industrial production. An important factor was the attempt to reconstruct Polish industry by using traditional methods, which did not require the purchase of the most modern technologies. Such a policy ultimately resulted in the reappearance of well-known Polish complex of the country being "underdeveloped" or "backward." In the [1950]s the IWP had no possibility to develop the modern design of electronic, household and other goods, mostly due to the fact that Poland still did not have professionals in industrial design. In this situation, Wanda Telakowska implemented a program that focused on the one hand on further adaptation of folk traditions in manufacturing to aesthetic and technological requirements of mass-scale production, and on the other on educating designers. [5] However, it was the collaboration of professional artists and folk creators that produced the most interesting results. Entire new design teams were formed and their activities concentrated on conforming local designs and techniques to industry requirements. [6]

Socialist realism in Poland did not last as long as in the Soviet Union and other countries of the Eastern bloc, nor was it nearly as strict and uncompromising. The information blackout was not total and hence Polish society was to some extent aware of models of consumerist lifestyle, including design. Following Stalin's death in [1953],

[1] I. Huml, Polska sztuka stosowana XX wieku, Warszawa 1978, passim.

[2] Polskie życie artystyczne w latach 1945-1960, ed.

A. Wojciechowski, Wrocław Warszawa Kraków 1992, pp. 347-350.

[3] <http://culture. pl/pl/artykul/polskie-wzornictwo-xx-wieku> [accessed on: 27.03.2016].
[4] K. Kubalska-Sulkiewicz, M. Bielska-Łach, A. Manteuffel-Szarota, Słownik terminologiczny sztuk pięknych, Warszawa 1997, p. 343, see also D. Crowley, Stalinism and Modernist Craft in Poland, "Journal of Design History” 1998, vol. 11, no. 1, pp. 71-83.

[5] Polskie życie artystyczne..., pp. 350-351.

[6] <http://culture. pl/pl/artykul/polskie-wzornictwo-xx-wieku> [accessed on: 27.03.2016]. 
the possibility of viewing western films and art exhibitions gradually increased. Fashion magazines reprinted some popular Paris collections, fabrics used bolder patterns, and Polish posters hardly fit the definition of socialist realism. In [1954] many Polish factories introduced so-called "designing teams," which employed graduates of art schools. The consumer products of industry from this period include the Syrena motor car, the Bajka slide projector and the Huragan racing bicycle. They were designed not by artists but by engineers and constructors, but in the years that followed it was from such designing teams that industrial designers emerged as well.

Władysław Gomułka's taking over of power[7] and the slightly more liberal political and economic attitude from the authorities after [1956] marked the beginning of a short period dubbed "The thaw." [8] One of its characteristics was a certain openness to contemporary western culture with all its individualism and a variety of lifestyles. This openness affected design as well. The design process was based on the intuitive selection of form in relation to the material, technology and function of the product, with no need to refer to tradition anymore. Simultaneously, a paradigm of "modernity" appeared, emerging from abstract art and organic design. The paintings of Pablo Picasso, sculptures of Henry Moore and furniture of Charles Eames defined new aesthetic and construction standards. This organic design inspired designers such as Maria Chomentowska or Jan Kurzątkowski, who expertly adapted these new forms to the technological capabilities of the Polish furniture industry. Ceramic tableware boasted several impressive designs, and among fabrics, patterns called in Poland "pikasy," inspired by abstract paintings and new figuration, became immensely popular. [9] Some of these fabrics were created as a result of aforementioned program launched by the Industrial Design Institute. In [1960] an independent Central Designing Bureau of the Light Industry originated from a part of the Institute. Its main field of activity was designing fabrics and clothes.

[1950]s interiors presented in films feature very characteristic and, at the same time, quite unimposing aesthetics of that time, perfectly illustrated by the [1955] film Irena do domu [Irene, Go Home!]. [10] Flats were small and this shortage of space necessitated combining the dining, rest, study, play and sleep areas in one room. The kitchen was always a separate room and it was usually modestly furnished with

[7] See D. Crowley, Design in Stalinist and Post-Stalinist Poland, "Journal of Design History" 1994, vol. 7, no. 3, p. 198.

[8] <https://pl. wikipedia. org/wiki/Odwil\%C5\%BC_ gomu\%C5\%82kowska> [accessed on: 27.03.2016].

[9] See D. Crowley, Stalinism and Modernist..., p. 77. [10] The film was directed by Jan Fethke. The main characters are married couple Zygmunt and Irena Majewscy. The husband, a foreman in one of Warsaw factories, is totally opposed to the idea of working women. Aware of this, his wife Irena hides the fact that she would like to acquire professional qualifications. She learns about a driver training course and enrolls, and in an effort to deceive her husband, has to organize her days to perfection. The film stars Lidia Wysocka as Irena Majewska and Adolf Dymsza as Zygmunt Majewski. 


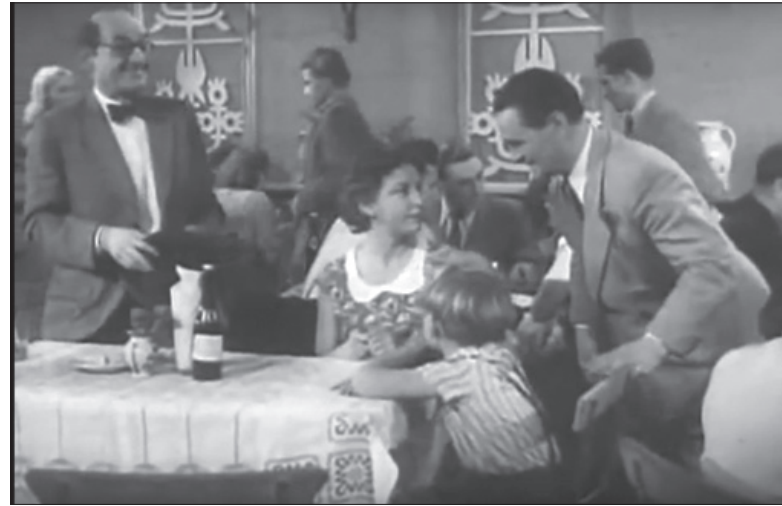

Il. 1. Irena do domu, dir. by Jan Fethke. A restaurant interior. On the walls: ethnic motifs, characteristic of the 50 . These motifs are also visible on the tablecloth that covers the table

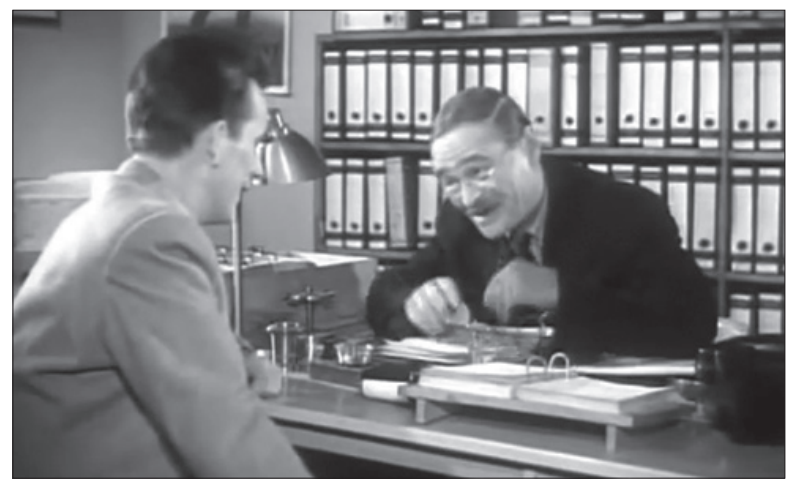

Il. 2. Sprawa do załatwienia, dir. by Jan Rybkowski and Jan Fethke. The 1950 s. public interior. City of Warsaw a characteristic pine sideboard with glass-panelled upper section painted in white oil paint, and a square or rectangular (hardly ever round) wooden table. The interior of a restaurant shown in the aforementioned film has equally unimpressive furnishings. The main decoration are folk-themed ornaments on the walls and their miniature replicas on the cloth covering the table, where the film's main character, Irena, sits with her family (il. [1]). In a slightly different way the film's scenographer presented the cloakroom in Irena's son's kindergarten. Multicolored cabinets decorated with miniature animals build up an atmosphere of a fairytale and, at the same time, show that the public interiors were arranged with greater attention to detail and aesthetics than private apartments. The same phenomenon may be noticed in the film Sprawa do załatwienia [Matter to Be Settled].[11] The interior of the public office clearly shows the imminent "modernity," signaled, for instance, by the latest model of a lamp on a clerk's desk (il. [2]). Another interesting aesthetic concept is the stylish interior of the laundry, where a character from the forementioned film comes to pick up a jacket. The room is fitted with stylized wooden furnishings and has a separate cash register, unseen nowadays (il. [3]).

The [1960]s brought about far-reaching changes throughout the world, which were also to influence the situation in Poland. In [1954] Ulm in West Germany saw the foundation of The School of Design, whose curriculum clearly separated the professions of a designer and an artist, assigning to the members of these two groups different goals and operating methods. Industrial design was set to become a discipline supported by technical and social sciences rather than by fine arts. The first sketchy bits and pieces of information about the activities and the teaching methodology of the Ulm School reached Poland in the early [1960]s. Here, as early as at the end of the previous decade, a new generation of designers - some of them with artistic and others with technical education - succeeded in introducing some significant changes in the designing community. IWP introduced three new areas of research: living interior, working
[11] It's a 1953 comedy directed by Jan Rybkowski and Jan Fethke. A television journalist tries to provide a piano for a community cultural centre. He meets a girl from the centre and together they have to face several obstacles, such as a gossip and a black-market operator in one, a rude taxi driver, a compulsive chatterbox, a churlish waiter, a bureaucrat-official, a corrupt salesperson, a football hooligan and many others. The film has a doubly optimistic ending the protagonists manage to acquire the piano and the two young people go for a romantic walk together. The film features Gizela Piotrowska and Bogdan Niewiniowski. 
clothes and ergonomics.[12] Simultaneously, a decision was made to initiate the program of collecting and processing data essential for designers, such as norms and standards, technical characteristics and parameters and the results of research carried out by physicists, chemists, as well as specialists in ergonomics and social studies. The new methodology developed in Ulm provided the theoretical background for these new activities, not only in the form of "scientific operationalism" but also through the

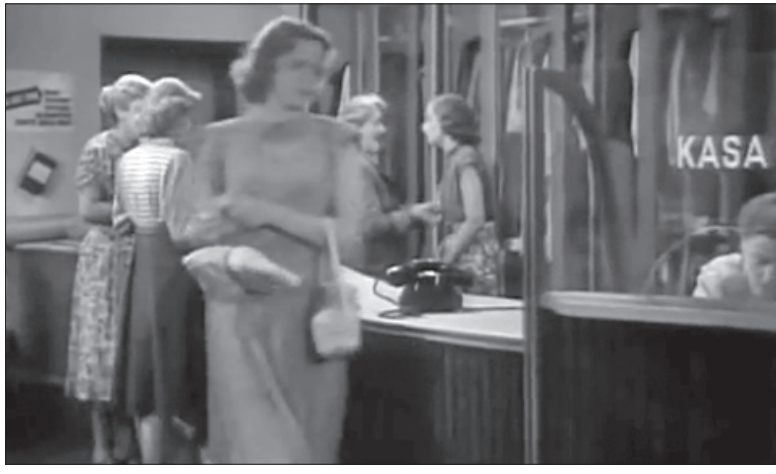

Il. 3. Sprawa do załatwienia, dir. by Jan Rybkowski and Jan Fethke. The 1950 . public interior. Elegant laundry room with a separate checkout counter education, as for the time being, in the best traditions of applied arts designers received their training in art schools. It is also true today and artistic disciplines are still an integral part of every designer's education process. Industrial design faculties gradually emerged from general design departments whose teaching staff were mainly artists and architects. In the [1960]s they were joined by engineers, who introduced the issues of industrial production into the curriculum. Already active faculties of industrial design expanded into full departments, based on the assumption that they would specialize in different areas of design. Hence furniture design was studied in Poznań, glass and ceramics in Wrocław, fabrics and fashion in Łódź, and ship furnishings in Gdańsk, while systems, ergonomics, rehabilitation equipment, home appliances and electronics in Cracow and Warsaw. These departments, usually employing the best specialists, became centers of local designer communities. In [1959] Rada Wzornictwa i Estetyki Produkcji Przemysłowej [The Council of Design and Aesthetics for Industrial Production] was created, and in [1963] Stowarzyszenie Projektantów Przemysłowych [The Industrial Designers Association] was founded. A milestone in the development of the whole designer community was the [1956] foundation of a new journal, "Projekt" [Design],[13] whose scope of interest included industrial design, applied graphics and arts and fine arts. Its graphic design is still a great testimony to professionalism and high skills of Polish graphic designers. More industrial design-oriented, though less popular, were the periodicals published by Industrial Design Institute, namely "Wiadomości IWP” [IWP News], which was later transformed into a newsletter, eventually to be replaced by a monthly publication "Design." The late [1950]s and the next decade are the period sometimes called in Poland "small stabilization," [14] with the authorities attempting to build a non-consumption society whose material needs are provided for on a very basic level by the state, which at the same

[12] Polskie życie artystyczne..., pp. 350-351.

[13] See D. Crowley, Stalinism and Modernist..., p. 198.
[14] <http://portalwiedzy. onet.pl/93821,,,,mala_stabilizacja,haslo. html $>$ [accessed on: 27.03.2016]. 
time offers a very broad social care. Yet this modest and seemingly honest program was a smokescreen concealing the government's effort to control all areas of life. Freedom of choice, the most characteristic quality of a democratic society, was limited and marginalized. As far as material goods were concerned, it meant coming to terms with the fact that the range of products that shops offered was very narrow. Despite this situation, industrial design still played a very important role on this centrally-planned market. Part of the funds previously allocated to heavy industry and military production were channeled into the production of new consumption goods and these obviously needed designing. New home appliances, telephones, radios, record players, television sets and photo cameras appeared on the market. [1958] saw the beginning of production of the popular Syrena car,[15] designed a few years previously. Good examples of modern Polish design from the [1960]s are RAMONA and EWA radios and BAMBINO record player. [16] The symbol of "modernity" was the [1959] OSA scooter, designed by Krzysztof Brun, Jerzy Jankowski, Tadeusz Mathia and Krzysztof Meisner.[17] Economic norms binding the construction industry forced production lines to deliver new, smaller furniture. The best known example of this trend was the so-called 'wall-unit', designed in [1962] by Bogusława and Czesław Kowalski. It was nicknamed "the Kowalskis' furniture," [18] although the name referred to an average Polish citizen rather than to its creators. In addition to enriching the somewhat poor assortment of products on the local market, industrial designers were given another important task: they were expected to contribute to the effort of increasing exports, especially to western countries. The inconvertibility of the Polish currency, the zloty, was responsible for continuous problems in the whole economy, which forced the government to go to great lengths to acquire hard currencies. Improved industrial design was expected to help in these efforts, however, the quality of products did not match their impressive design and the merchandise ended up on Third World or local markets. Additionally, from the early [1960]s designers were also expected to co-operate with the machine industry and conduct ergonomic research. Some of the leading designers who undertook these tasks were Andrzej Pawłowski, Adam Wodnicki, Olgierd Rutkowski and Rafał Kwinto.

Obviously film sets from [1960]s can hardly be considered an absolute source of iconographic inspirations for industrial design, but some big screen examples clearly reflect the idea for interior design and

[15] Fabryka Samochodów Osobowych 1951-1976, Warszawa 1976; A. Rummel, Polskie konstrukcje i licencje motoryzacyjne w latach 1922-1980, Warszawa 1985; A. Zieliński, Polskie konstrukcje motoryzacyjne w latach 1947-1960, Warszawa 1985.

[16] See Rzeczy pospolite, polskie wyroby 1899-1999, ed. Cz. Frejlich, Olszanica 2001, pp. 160-161; Historia Zakładu 1945-1970; Instrukcja serwisowa gramofonu ze wzmacniaczem Bambino typ WG-251.
[17] See Rzeczy pospolite..., pp. 142-143; A. Zieliński, op.cit.

[18] J. Pańkowski, Meble do małych mieszkań, "Wiadomości IWP" 1963, no. 3-4, pp. 12-25; Meble do małych mieszkań, "Biuletyn Rady Wzornictwa i Estetyki Produkcji," Warszawa 1963, no 5, pp. 14; D. Wróblewska, Nowe typy umeblowania, "Projekt" 1963, no. 2, pp. 9-11. 
the nature of certain designer novelties of that time. One such example is the office where Joanna, the main protagonist of Lekarstwo na miłość [Cure for Love][19], works. Large windows let in plenty of light and this, combined with the room's simple furnishings, speaks of functionality. The "pikasy"-patterned curtains testify to how well certain elements of [1950]s style assimilated themselves with [1960]s trends (il. [4]).

Equally modern is the interior of the Warsaw water supply station, nicknamed "Gruba Kaśka" [Fat Kate] from the film Pieczone gołabki [There is No Free Lunch][20] and the station director's office, which boasts upholstered armchairs with legs made of cold-bent stainless steel - pieces of furniture that were very characteristic of "modernist" design.[21] Also the main protagonist of the film Człowiek $z M$-[3] [Man with an Apartment],[22] Tomasz, is no stranger to novelties. He is employed in a very modern hospital (il. [5]) and, forced by his mother, regularly attends an exclusive tennis club, where his favorite place is

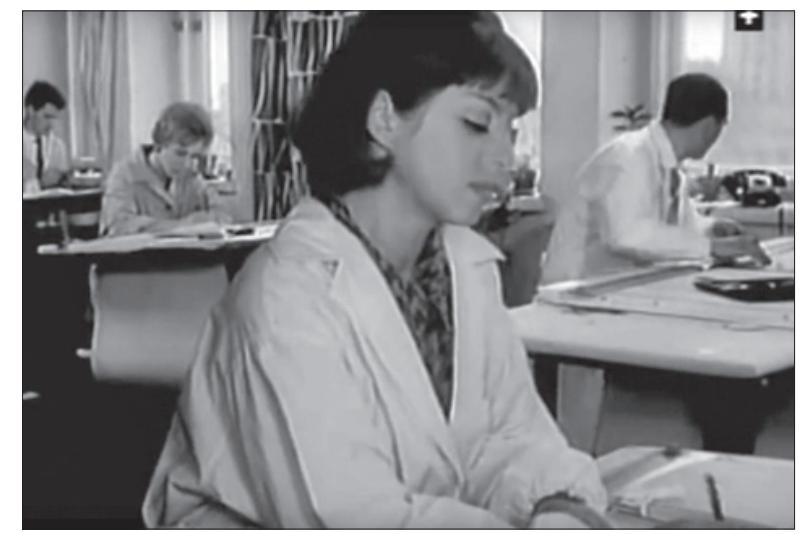

[19] One of the most popular Polish romantic comedies. Created in 1966, it was directed by Jan Batory. The leading role is played by the famous Kalina Jędrusik, who is supported by such big names in Polish cinema as Wieńczysław Gliński, Andrzej Łapicki, Mieczysław Czechowicz, Jacek Fedorowicz and Krystyna Sienkiewicz. The plot is based on the novel by Joanna Chmielewska and tells the amusing story of a young woman engaged in a private investigation of a gang of forgers. Joanna (Kalina Jędrusik), an attractive architect, never leaves home, waiting for her beloved Janusz (Wieńczysław Gliński) to phone her. She gets a few calls from men who have dialed her number by mistake and inadvertently becomes a dispatcher for gang members. Completely unaware of the situation, the girl agrees to meet Andrzej, one of the callers (Andrzej Łapicki). Intrigued by his mysterious behavior, she comes to the conclusion that she has met the gang leader. She decides to follow him with the help of her friend Janka (Krystyna Sienkiewicz). Soon she gets kidnapped, which triggers a series of even more hilarious events.

[20] The staff of the Warsaw water supply station, colloquially called "Gruba Kaśka” [Fat Kate] are almost exclusively layabouts and wheeler-dealers. Their less-than-enthusiastic attitude to work results in frequent breakdowns and crashes that take weeks to repair and irritate the inhabitants of Warsaw. Trying to find a solution, the station director employs a young poet Leopold Górski, who receives the task of keeping his workmates awake, as they often fall asleep to the monotonous sounds of pumps. Leopold is just like his heart-warming poems, always friendly and cheerful, even though he has his own share of problems. Every day he has to commute to work from a small town near Warsaw, where he rents a room in a little wooden cottage by the railway. The passing trains shake the rickety hut, which brings the poet to the verge of a nervous breakdown. Leopold dreams of a flat of his own, but when the station management gets one to allocate, the naive softy gives up the opportunity not in favor of a more needy, as he thinks, but of simply more cunning, workmate. Instead of a flat, the station's party secretary entrusts him with a special and delicate mission - he has to improve the morale of the worst crew, headed by foreman Wierzchowski. Of course, after some time its members become model workers, Leopold finally gets his longed-for apartment, and his feelings towards charming Kasia are returned. This 1966 film was directed by Tadeusz Chmielewski and stars Krzysztof Litwin as the poet and Magdalena Zawadzka as Kasia.

[21] <http://modernizmgdyni. pl/?p=1083> [accessed on: 27.03.2016].

[22] This 1969 film tells the story of Tomasz (played by Bogumił Kobiela), a young orthopedist who has to get married quickly if he wants to get his dream three-room apartment, as it cannot be allocated to a single person. He has thirty days to find a suitable wife, but he's determined to find one that he might love as well. The first candidate is too stubborn, the next too jealous, the third too self-reliant and. Finally, 


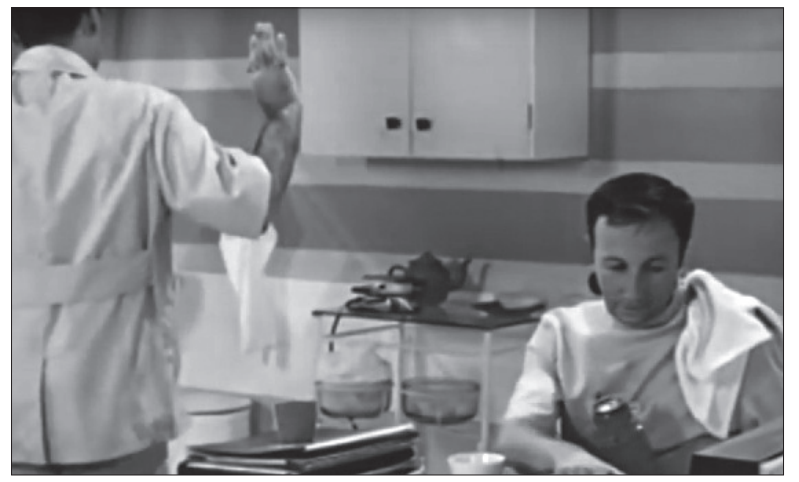

the bar equipped with a characteristic screen made of bicolored, trapezoid-shaped empty panels dividing the space into two parts, yet in such a way that the parts still constitute one room (il. [6]).

Similarly innovative solutions begin to appear in the appearance of living interiors. The bathroom from the commercial seen in the film Małżeństwo z rozsądku [The Marriage of Convenience],[23] is fitted with a cast iron bathtub immensely popular in the [1960]s, cast iron

Il. 5. Człowiek $z M-3$, dir. by Leon Jeannot. The end of the 1960 . The very modern interior of the hospital where the main character of the film Tomasz was employed bathtub, a wall-mounted bath unit and simple beige tiles. The bathroom in the flat that Człowiek $z M-[3]$ tries to acquire is equally modern. "Does it all work?" asks Tomasz's mother, startled, as she looks at the toilet water tank flushing string and its pear-shaped porcelain handle. The interior of Joanna's apartment in Lekarstwo na miłość also shows some technological novelties. In the kitchen there is a refrigerator and a double sink with an additional panel that protects the wall from water (il. [7]), whereas the

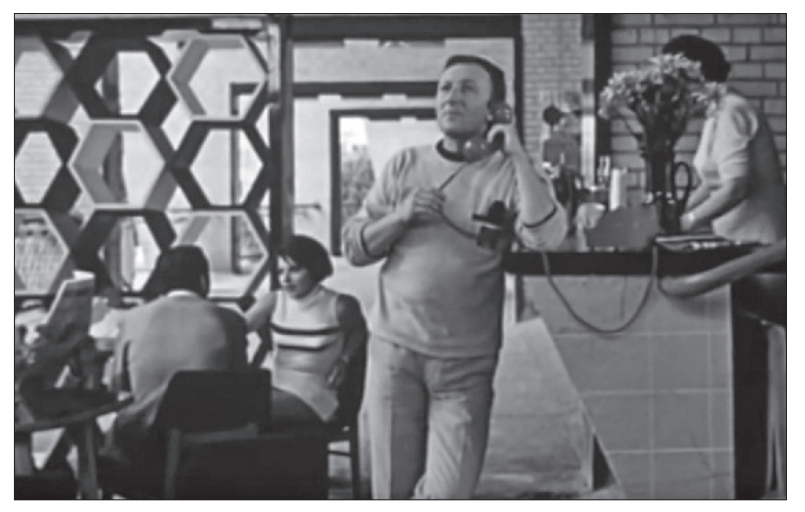

guest bedroom is equipped with a radio. Quite a similar radio, along with a TV set can be seen in the film Matżeństwo z rozsądku.

Still, the central consumption item that every Pole aspired to possess in the [1970]s and the [1980]s was a "cheap, well-made and functional" wall-unit, bought, of course, on an installment plan. It was made of firewood and covered with wood veneer. Its open shelves were often stacked with another characteristic decorative elements of Polish homes - crystal vases (il. [8]). However, not everyone was equally hap-

Il. 6. Człowiek $z$ M-3, dir. by Leon Jeannot. The end of the 196os. The bar of a luxury tennis club where Tomasz played py with this "modernity." The mother of one of the main protagonist of Sami swoi[24] [Our Folks], a [1966] comedy, although happy that in the new home she will also have her favorite sleeping place behind the stove, still grumbles, "Everything would be better without this electricity." A different reality appears to us in a foreign romantic comedy from the [1950]s and [1960]s, and especially in American film. After at the last possible moment Tomasz manages to find the perfect one and marry her. The film was directed by Leon Jeannot.

[23] Joanna, the daughter of an affluent trader operating in a big marketplace, is in love with Andrzej, a young and talented, yet very poor painter. The girl's father decides to find her a suitable husband. The shrewd merchant wants to conceal his wealth from the authorities, therefore a perfect candidate for his son-in-law must be the man of such social status that would justify the villa, the car and other luxuries. Eventually he chooses Andrzej, who tries to sell his painting near the Barbakan in Warsaw. The film is a 1967 romantic comedy directed by Stanisław Bareja, and it stars Elżbieta Czyżewska as Joanna and Daniel Olbrychski as Andrzej.

[24] Sami swoi (1967) is the first part of an excellent trilogy by Sylwester Chęciński. The film tells the story of two feuding families, the Pawlaks and the Karguls, who shortly after World War II are forced to leave the eastern borderlands of Poland (known as the 'Kresy') and relocate to western "recovered territories” (Ziemie Odzyskane). The conflict, which dates from before the war, started over trivial matters but 
World War II America was stronger than ever. While the average Pole struggled with housing problems, staying mostly in the same family home well into adulthood, the American decorated a house in the suburbs. "In the family vision of a home in the suburbs: the utopias presented mainly white middle-class mums, smiling dads with some white collar work in big kind corporations and good, healthy children - all living happily in modern, spacious homes with contemporary furniture and the latest household appliances... well, of course,

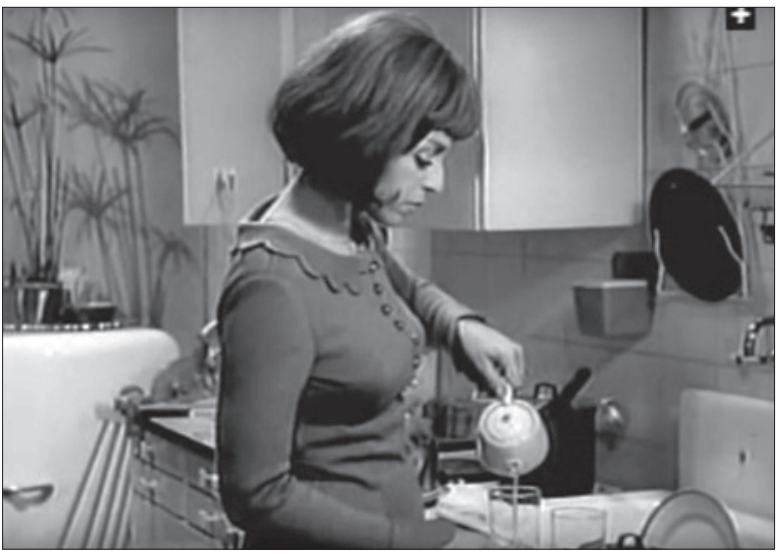
with a huge station wagon parked at the front." [25] For the average Pole the biggest dream was a Syrena mentioned earlier or an FSO Warszawa car, and in the late [1960]s, an Italian Fiat [125] p., a GerIl. 7. Lekarstwo na miłość, dir. by Jan Batory. Joanna’s kitchen man Wartburg or possibly a Russian Volga. In terms of modern furniture, they were not on general sale, they had to be booked, waited for, and possibly bought, as long as the furniture pattern currently on official was appreciated by the potential buyer.

The full picture of American longing for luxury and lifestyle based on an incomparable level of consumption can be seen in the [1954] film Sabrina. Sabrina is the daughter of a driver working for the wealthy Larrabee family living in Long Island and having an office in New York. She is in love, albeit unrequitedly, with one of his father's bosses, David Larrabee. Sabrina's room is located above a garage adjacent to the Larrabee residence, and is furnished with cheap furniture from the end of the previous century, manufactured by Thonet (bed, rocking chair, round table and chairs).[26]

The apartment located near Central Park, rented by Calvin Clifford Baxter, a New York-based insurance bookkeeper, in the romantic [1960]'s comedy The Apartment, is similarly furnished. On the other hand, Holly Golightly and her neighbor, Mr. Berman, the

Il. 8. Małżéstwo z rozsądku, dir. by Stanisław Bareja. The end of the 1960s. The fragment of Joanna's parents' kitchen, and in the background there is a room combining a function of a living room, dining room and bedroom which ultimately led to violence and bloodbath that forced Jan Pawlak to flee to America in order to avoid revenge for wounding his neighbor Kargul. Years later he returns to Poland and finds his brother Kazimierz living in peace next door to Kargul. To mollify Jan's anger, his brother tells him the story of the reconciliation that was greatly helped by his son Witia marrying Kargul's daughter Jadźka. In the cast we can see the Pawlaks: Wacław Kowalski as Kazimierz Pawlak (as well as Kazimierz and Jan's father in flashback), Zdzisław Karczewski as Jan 'John', Jerzy Janeczek as Witia, Maria Zbyszewska as Mania (Pawlak's wife), Natalia Szymańska as Leonia (Pawlak's mother), Zyg- munt Bielawski as Paweł (Pawlak's son) and the Karguls: Władysław Hańcza as Władysław Kargul, Ilona Kuśmierska as Jadwiga (Kargul's daughter 'Jadźka') and Halina Buyno-Łoza as Aniela (Kargul's wife). [25] Ch. Fiell, P. Fiell, The Story of Design, London, 2013, p. 349.

[26] See Ch. Wilk, Introduction, in: Thonet Bentwood and Other Furniture: 1904, Illustrated Catalogue, New York 2004; J. Wojciechowska-Kucięba, Polskie meble gięte. Wytwórnia "Polski Przemyst Drzewny-Czerski i Jakimowicz" w Bondyrzu i we Lwowie 1922-1939, Lublin 2012, pp. 11-25. 


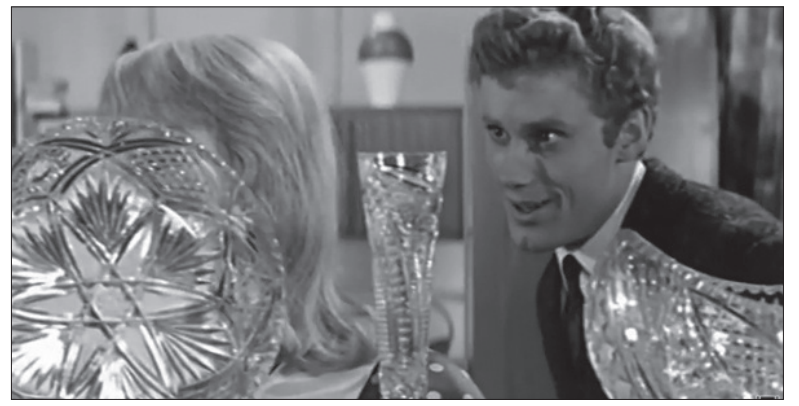

main characters of the [1961] film Breakfast at Tiffany's live in a very modern apartments. At the centre of Holly's living-room there is a very original sofa resembling a bathtub with a battery attached to the backrest. Mrs. Golightly's kitchen is also very modern, with simple cabinets made of lacquered white plywood and luxury household appliances (toaster, coffee machine, kitchen aid, gas cooker and fridge).

Il. 9. Małżeństwo z rozsąd$k u$, dir. by Stanisław Bareja. The end of the 1960s. Polish crystals and popular Kowalskis' wall unit furniture
[27] See Ch. Fiell, P. Fiell, op.cit., p. 350; R.K. Ferman, Postwar Interior Design; 1945-1960, New York 1987, p. 8 .

[28] I. Huml, op.cit., p. 176.
The same applies to the apartment of her neighbor and artist-photographer. Every time he opens the door, because his giddy neighbor constantly forgets the keys to her apartment, he stumbles over "designer" lamps and cabinets. Full of inspiration for modernity is the luxurious office of the millionaire Linus Larrabee ([1954]'s Sabrina) with its enormous heavy art deco conference table and swivel leather armchairs set around it and a clothes hangers designed by the Eames. [27] Similarly, Baxter's New York office (The Apartment) is full of inspirational solutions such as leather seats with the backrest in the form of a fan or modern counting machines.

Even in the [1954] film Roman Holiday, where the interior decorator clearly focused on conveying the atmosphere of eternal Rome, he presents the office of editor-in-chief Joe Bradley, furnished with a light colored bookcase on cone-shaped thin legs, standing along one of the walls. The bookcase has sliding doors made of thin plywood and is a precursor of new designs of the late [1960]s and [1970]s.

Taking into consideration the above-mentioned examples of interiors in the Polish and foreign romantic comedies of the [1950]s and [1960]s, we can see that the interiors the characters of a very high social status were presented in, were still in the Louis and Biedermeier style, rarely in art deco. The characters of the middle class can be seen not so much in the modern interior, but in the interior, which embodies a mixed style, often with the help of props such as cheap Thonet furniture. Interiors in clean modern style were reserved for the public buildings: offices, banks, restaurants and hospitals.

In Poland, attempts were made to use all the "design innovations" coming from the west, however, the ever closed Polish borders prevented them from spreading freely. We had to use local designers. In the [2]nd half of the twentieth century, a period which Prof Irena Huml called "the invasion of modernity" started.[28] The doctrine of socialist realism was rejected and the focus was on modernity. Innovation became the most desirable feature of a work of art, and modernity - the most important concept.[29] It was a very creative period in Polish design and the time of outstanding progress, which influenced
[29] A. Frąckiewicz, Cały ten zgietk. Uwagi o stylu lat 50. XX wieku w polskim wzornictwie, in: W kregu sztuki przedmiotu, ed. M. Dłutek, A. Kostrzyńska-Miłosz, Warszawa 2011, p. 27. 
later achievements. In the middle of this decade, the famous Polish film school[30] was formed and the most important premieres were made, among others: in [1957] - Wajda's Kanat [Kanal], [1958] - Popiót i Diament [Ashes and Diamonds],[31] Munk's Eroica, Pożegnania [Farewells] Hasa, [1959] - Kawalerowicz's Pociąg [Train], [1961] - Kawalerowicz's Matka Joanna od Aniołów [Mother Joan of the Angels], and [1962] - Polański’s Nóż $w$ wodzie [Knife in the Water]. As for the arts, it was the time when artists wanted to be modern. "We strive for a beautiful, glorious future, but we can not yet see its shape... We want and demand from the art that it will bring us this good, just, and happy life." [32] First of all, the design was to bring beauty to everyday life and shape the human environment in accordance with the spirit of the time and the demands of the present day. At the same time, the belief in art serving society was not rejected. Unfortunately, the epoch of ferment and revival did not last long, just for one decade. In the first half of the [1960]s there was a renewed change in the cultural policy of the state, a gradual intensification of censorship and restriction of civil liberties. [33] This phenomenon obviously manifested itself in Polish artistic life. However, most of the achievements of Polish design in the [1950]s and [1960]s and proposals of contemporary designers turned out to be not only very innovative but lasting, serving Poles for the next few decades. Unfortunately, some of these solutions only exist in film and in museums, and that is just the extra role of the film, to record so that some phenomena, in this case, artistic phenomena, do not sink into oblivion.

Crowley D., Design in Stalinist and Post-Stalinist Poland, "Journal of Design History" [1994], vol. [7], no. [3], pp. [187]-[203]

Crowley D., Stalinism and Modernist Craft In Poland, "Journal of Design History" [1998], vol. [11], no [1], p. [71]-[83]

Fabryka Samochodów Osobowych [1951]-[1976], Warszawa [1976]

Ferman R.K., Postwar Interior Design, [1945]-[1960], New York [1987]

Fiell Ch., Fiell P., The Story of Design, London [2013]

Frąckiewicz A., Cały ten zgietk. Uwagi o stylu lat [50]. XX wieku w polskim wzornictwie, in: W kręgu sztuki przedmiotu, ed. M. Dłutek, A. Kostrzyńska-Miłosz, Warszawa [2011], p. [26]-[37]

Historia Zakładu [1945]-[1970], Łódź

Hryniewiecki J., Kształt przyszłości, "Projekt” [1956], issue [1], p. [7]

Huml I., Polska sztuka stosowana XX wieku, Warszawa [1978]

Kubalska-Sulkiewicz K., Bielska-Łach M., Manteuffel-Szarota A., Słownik terminologiczny sztuk pięknych, Warszawa [1997]

[30] T. Miczka, Cinema under political pressure: a brie outline of authorial roles post-war feature-film 1945-1995, "Kinema", 1995, Issue 4, p. 36.

[31] See A. Misiak, National Sentiments in Andrzej Wajda's Contemporary Film Epies, "Journal of Film and Video" 2013, vol. 65, no. 3, p. 23.
[32] J. Hryniewiecki, Kształt przyszłości, "Projekt", 1956, Issue 1, p. 7.

[33] A. Frąckiewicz, Cały ten zgiełk ..., p. 37. 
Meble do małych mieszkań, "Biuletyn Rady Wzornictwa i Estetyki Produkcji" [1963], no. [5], p. [14]

Miczka T., Cinema under political pressure: a brief outline of authorial roles post-war feature [1945]-[1995], "Kinema” [1995], Fall, issue [4], pp. [32]-[48]

Misiak A., National sentiments in Andrzej Wajda's contemporary film Epies, "Journal of Film and Video" [2013], vol. [65], no. [3] (Fall), pp. [26]-[39]

Pańkowski J., Meble do małych mieszkań, "Wiadomości IWP” [1963], no. [3]-[4], pp. [12]-[25]

Polskie życie artystyczne w latach [1945]-[1960], ed. A. Wojciechowski, Wrocław Warszawa Kraków [1992]

Rummel A., Polskie konstrukcje i licencje motoryzacyjne w latach [1922]-[1980], Warszawa [1985]

Rzeczy pospolite, polskie wyroby [1899]-[1999], ed. Cz. Frejlich, Olszanica [2001]

Wilk Ch., Introduction, in: Thonet Bentwood and Other Furniture: [1904], Illustrated Catalogue, New York [2004]

Wojciechowska-Kucięba J., Polskie meble gięte. Wytwórnia "Polski Przemysł Drzewny-Czerski i Jakimowicz" w Bondyrzu i we Lwowie [1922]-[1939], Lublin [2012], pp. [11]-[25]

Wróblewska D., Nowe typy umeblowania, "Projekt" [1963], no. [2], pp. [9]-[11]

Zieliński A., Polskie konstrukcje motoryzacyjne w latach [1947]-[1960], Warszawa [1985]

Webpages

$<$ http://culture. pl/pl/artykul/polskie-wzornictwo-xx-wieku>

$<$ http://modernizmgdyni. pl/?p=[1083]>

$<$ https://pl. wikipedia. org/wiki/Odwil\%C[5]\%BC_gomu\%C[5]\%[82]kowska> $<$ http://portalwiedzy. onet. pl/[93821],,,,mala_stabilizacja,haslo. html> 